Article

\title{
Crystal Structure Refinements of Four Monazite Samples from Different Localities
}

\author{
M. Mashrur Zaman and Sytle M. Antao *(D) \\ Department of Geoscience, University of Calgary, Calgary, AB T2N 1N4, Canada; mmzaman@ucalgary.ca \\ * Correspondence: antao@ucalgary.ca
}

Received: 21 October 2020; Accepted: 15 November 2020; Published: 18 November 2020

\begin{abstract}
This study investigates the crystal chemistry of monazite $\left(A \mathrm{PO}_{4}\right.$, where $A=$ Lanthanides $=\mathrm{Ln}$, as well as $\mathrm{Y}, \mathrm{Th}, \mathrm{U}, \mathrm{Ca}$, and $\mathrm{Pb}$ ) based on four samples from different localities using single-crystal $\mathrm{X}$-ray diffraction and electron-probe microanalysis. The crystal structure of all four samples are well refined, as indicated by their refinement statistics. Relatively large unit-cell parameters $(a=6.7640(5)$, $b=6.9850(4), c=6.4500(3) \AA, \beta=103.584(2)^{\circ}$, and $\left.V=296.22(3) \AA^{3}\right)$ are obtained for a detrital monazite-Ce from Cox's Bazar, Bangladesh. Sm-rich monazite from Gunnison County, Colorado, USA, has smaller unit-cell parameters $\left(a=6.7010(4), b=6.9080(4), c=6.4300(4) \AA, \beta=103.817(3)^{\circ}\right.$, and $\left.V=289.04(3) \AA^{3}\right)$. The $a, b$, and $c$ unit-cell parameters vary linearly with the unit-cell volume, $V$. The change in the $a$ parameter is large $(0.2 \AA)$ and is related to the type of cations occupying the $A$ site. The average $\langle A-\mathrm{O}\rangle$ distances vary linearly with $V$, whereas the average $<\mathrm{P}-\mathrm{O}>$ distances are nearly constant because the $\mathrm{PO}_{4}$ group is a rigid tetrahedron.
\end{abstract}

Keywords: monazite; crystal structure; chemical analysis; structural variations

\section{Introduction}

Monazite is a phosphate mineral that contains significant variations in lanthanide ( $\mathrm{Ln}$ ) elements. The general chemical formula is $A \mathrm{PO}_{4}$, where $A=\mathrm{Ln}, \mathrm{Y}, \mathrm{Th}, \mathrm{U}, \mathrm{Ca}$, and $\mathrm{Pb}$ atoms. Although monazite can accommodate trivalent $\left(\mathrm{Ln}^{3+}, \mathrm{Y}^{3+}\right)$, tetravalent $\left(\mathrm{Th}^{4+}, \mathrm{U}^{4+}\right)$, and divalent $\left(\mathrm{Ca}^{2+}, \mathrm{Pb}^{2+}\right)$ cations at the $A$ site, their potential substitutional effects on the structural properties are not fully understood. Monazite contains up to $32 \mathrm{wt}$.\% $\mathrm{ThO}_{2}$, but less than $0.5 \mathrm{wt}$ \% $\mathrm{UO}_{2}$. Small amounts of $\mathrm{Y}, \mathrm{Sc}, \mathrm{Ca}, \mathrm{Mg}, \mathrm{Fe}$, $\mathrm{Al}, \mathrm{Zr}, \mathrm{Mn}, \mathrm{Be}, \mathrm{Sn}, \mathrm{Ti}$, and Ta atoms may occur in monazite. The wide range in chemical variability makes monazite-type minerals useful for sequestration of nuclear waste [1]. Three major charge-balancing substitution mechanisms occur in monazite: (1) $(\mathrm{Th}, \mathrm{U})^{4+}+\mathrm{Ca}^{2+}=2 \mathrm{REE}^{3+}$, (2) $(\mathrm{Th}, \mathrm{U})^{4+}+\mathrm{Si}^{4+}=$ $\mathrm{REE}^{3+}+\mathrm{P}^{5+}$, (3) $4 \mathrm{REE}^{3+}=3(\mathrm{Th}, \mathrm{U})^{4+}+$ Vacancy [2-4] (where REE represents rare-earth elements).

The crystal structure of phosphate minerals with trivalent $\mathrm{La}, \mathrm{Ce}, \mathrm{Pr}$, and $\mathrm{Nd}$ cations was determined by X-ray diffraction techniques in 1944 for the Manhattan Project [5]. Those crystals were dimorphic: a monoclinic phase is isomorphous with monazite and the other is a new hexagonal phase. The crystal structure of monazite was first investigated using a sample from Ishikawa-yama, Fukushima Prefecture, Japan [6]. The refined structure gave very high R-values and unreliably large P-O distances. The structure of monazite from a beach sand sample from Kerala shows small structural differences after heat treatments up to $1130{ }^{\circ} \mathrm{C}$, but large $\mathrm{P}-\mathrm{O}$ distances were obtained [7]. A natural monazite sample with the formula $\left(\mathrm{Ce}_{0.51} \mathrm{La}_{0.29} \mathrm{Nd}_{0.14} \mathrm{Pr}_{0.05} \mathrm{Sm}_{0.01}\right)_{\Sigma 1.00}\left(\mathrm{PO}_{4}\right)$, was structurally characterized in Reference [8] and some synthetic samples were characterized in Reference [9]. Unit-cell parameters for monazite-Sm from the Annie Claim \#3 granitic pegmatite, southeastern Manitoba, Canada, were obtained using both single-crystal X-ray diffraction (SCXRD) and powder X-ray diffraction (PXRD) [10]. Unit-cell parameters of two monazite samples from different localities were obtained using the PXRD technique [11]. No structural characterization of Th-bearing monazite is available. The crystal 
structures of synthetic monazite compounds however are available $[2,12,13]$. High-temperature and high-pressure work was reported for monazite [14].

Monazite is monoclinic (space group $P 2_{1} / n ; \mathrm{Z}=4$ based on the formula $A \mathrm{PO}_{4}$ ). The structure is made up of irregular 9-coordinated $A$ site polyhedral linked together by distorted tetrahedral $\mathrm{PO}_{4}$ groups [8,15]. The $\mathrm{PO}_{4}$ tetrahedra are isolated and separated by intervening $A \mathrm{O}_{9}$ polyhedra (Figure 1). The $\mathrm{O}$ atom is coordinated to one $\mathrm{P}$ and two $A$ atoms. The $A \mathrm{O}_{9}$ polyhedra and $\mathrm{PO}_{4}$ tetrahedra form chains sharing $\mathrm{O}-\mathrm{O}$ edges along the $\mathbf{c}$ axis [2].

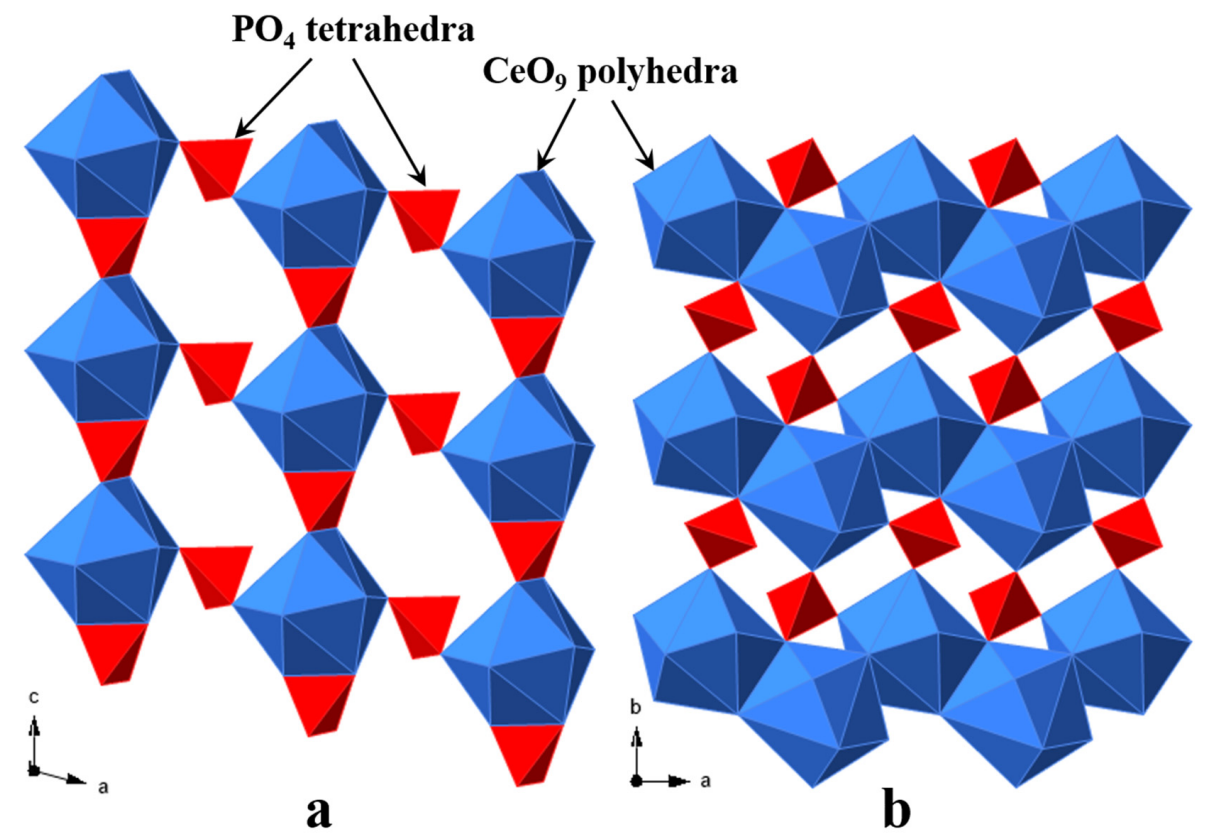

Figure 1. Polyhedral representation of the monazite structure: (a) isolated $\mathrm{PO}_{4}$ tetrahedra and $\mathrm{CeO}_{9}$ polyhedra that share edges or corners to form chains parallel to the $\mathbf{c}$ axis, and (b) $\mathrm{CeO}_{9}$ polyhedra share common edges along the (a) axis, whereas $\mathrm{PO}_{4}$ tetrahedra and $\mathrm{CeO}_{9}$ polyhedra share corners along the (b) axis.

This study investigates the crystal chemistry of four monazite samples from different localities using SCXRD and electron-probe microanalysis (EPMA). Variations among unit-cell parameters, bond distances, and chemical compositions of monazite are explained using crystal-chemical principles.

\section{Experimental Methods}

\subsection{Sample Description}

Two detrital ( 1 and 3 ) and two pegmatitic ( 2 and 4 ) monazite samples were used in this study (Table 1). The detrital monazite-rich heavy mineral fractions were separated from two raw beach placer sand samples collected from Cox's Bazar, Bangladesh. Zircon samples from this locality were previously characterized [16,17]. Fragments of monazite crystals were separated from the pegmatitic samples using a knife. All the samples were examined with a stereomicroscope and a polarizing microscope to assess their physical and optical characteristics. High-quality, inclusion-free, and high-purity crystals were selected for examination using single-crystal X-ray diffraction (SCXRD) and electron-probe microanalysis (EPMA), as described below.

\subsection{Electron-Probe Microanalysis (EPMA)}

The chemical composition of the monazite samples was obtained using a JEOL JXA-8200WD-ED electron-probe microanalyzer (Akishima, Tokyo, Japan) using the same crystal that was used for 
single-crystal data collection. The JEOL operating program on a Solaris platform was used for ZAF (atomic number; absorption, and flouresence) correction and data reduction. The wavelength dispersive (WD) analysis was conducted quantitatively using an accelerated voltage of $15 \mathrm{kV}$, a beam current of $2 \times 10^{-8} \mathrm{~A}$, and a beam diameter of $5 \mu \mathrm{m}$. Peak overlapping problems in the elemental analysis of monazite are very common and were solved following the method previously described [18]. Various minerals and compounds were used as standards $\left(\mathrm{CePO}_{4}\right.$ for $\mathrm{Ce}$ and $\mathrm{P}, \mathrm{NdPO}_{4}$ for $\mathrm{Nd}, \mathrm{YPO}_{4}$ for Y, $\mathrm{ThO}_{2}$ for Th, $\mathrm{LaPO}_{4}$ for $\mathrm{La}, \mathrm{SmPO}_{4}$ for $\mathrm{Sm}, \mathrm{PrPO}_{4}$ for Pr, GdPO 4 for Gd, DyPO for Dy, EuPO for $\mathrm{Eu}, \mathrm{TbPO}_{4}$ for $\mathrm{Tb}$, zircon for $\mathrm{Si}, \mathrm{Cr}$-augite for $\mathrm{Ca}$, barite for $\mathrm{S}$, pyromorphite for $\mathrm{Pb}, \mathrm{UO}_{2} \mathrm{for} \mathrm{U}$, and hornblende for Fe). Qualitative energy-dispersive spectra (EDS) shows what elements are present in the sample and then quantitative analyses were obtained. Fourteen spots were analyzed for each sample. The oxide wt.\% and the atom per formula unit ( $a p f u)$, based on four $\mathrm{O}$ atoms, are given in Table 2.

Table 1. Localities and description for the four monazite samples examined in this study.

\begin{tabular}{ccc}
\hline Sample & Localities & Descriptions and Occurrences \\
\hline 1 & Kolatoli beach, Cox's Bazar, Bangladesh & $\begin{array}{c}\text { Detrital monazite grains separated from a bulk beach } \\
\text { sand sample. Grains are spherical in shape and } \\
\text { greenish yellow. }\end{array}$ \\
3 & Shaplapur paleobeach, Cox's Bazar, \\
Bangladesh & Massive monazite occurs in a quartz pegmatitic rock. \\
4 & Gunnison County, Colorado, USA & $\begin{array}{c}\text { Same as sample 1. } \\
\text { cleavelandite, feldspar, and lepidolite from the } \\
\text { brown Derby-1 pegmatite. }\end{array}$ \\
\hline
\end{tabular}

Table 2. Electron-probe microanalysis (EPMA) data for the four monazite samples examined in this study.

\begin{tabular}{|c|c|c|c|c|c|c|c|c|c|}
\hline Sample & 1 & 2 & 3 & 4 & & 1 & 2 & 3 & 4 \\
\hline \multicolumn{6}{|c|}{ Oxide wt.\% } & \multicolumn{4}{|c|}{$a p f u$ * } \\
\hline $\mathrm{La}_{2} \mathrm{O}_{3}$ & 13.98 & 7.65 & 11.36 & 3.80 & $\mathrm{La}$ & 0.200 & 0.113 & 0.166 & 0.057 \\
\hline $\mathrm{Ce}_{2} \mathrm{O}_{3}$ & 28.42 & 22.42 & 25.24 & 12.42 & $\mathrm{Ce}$ & 0.404 & 0.330 & 0.367 & 0.185 \\
\hline $\mathrm{Pr}_{2} \mathrm{O}_{3}$ & 2.80 & 3.25 & 2.58 & 1.92 & $\operatorname{Pr}$ & 0.040 & 0.048 & 0.037 & 0.029 \\
\hline $\mathrm{Nd}_{2} \mathrm{O}_{3}$ & 12.05 & 15.31 & 11.24 & 7.12 & $\mathrm{Nd}$ & 0.167 & 0.220 & 0.159 & 0.104 \\
\hline $\mathrm{Sm}_{2} \mathrm{O}_{3}$ & 1.81 & 4.01 & 1.97 & 13.73 & Sm & 0.024 & 0.056 & 0.027 & 0.193 \\
\hline $\mathrm{Eu}_{2} \mathrm{O}_{3}$ & 0.11 & bdl & bdl & bdl & $\mathrm{Eu}$ & 0.001 & 0.000 & 0.000 & 0.000 \\
\hline $\mathrm{Gd}_{2} \mathrm{O}_{3}$ & 1.23 & 2.33 & 1.83 & 5.77 & $\mathrm{Gd}$ & 0.016 & 0.031 & 0.024 & 0.078 \\
\hline $\mathrm{Tb}_{2} \mathrm{O}_{3}$ & bdl & 0.11 & bdl & bdl & $\mathrm{Tb}$ & 0.000 & 0.001 & 0.000 & 0.000 \\
\hline $\mathrm{Dy}_{2} \mathrm{O}_{3}$ & 0.25 & 0.79 & 0.96 & 0.27 & Dy & 0.003 & 0.010 & 0.012 & 0.003 \\
\hline $\mathrm{Y}_{2} \mathrm{O}_{3}$ & 0.51 & 3.92 & 3.31 & 0.73 & Y & 0.011 & 0.084 & 0.070 & 0.016 \\
\hline $\mathrm{CaO}$ & 1.80 & 0.27 & 1.01 & 2.89 & $\mathrm{Ca}$ & 0.075 & 0.012 & 0.043 & 0.126 \\
\hline $\mathrm{FeO}$ & bdl & bdl & bdl & bdl & $\mathrm{Fe}$ & 0.000 & 0.000 & 0.000 & 0.000 \\
\hline $\mathrm{P}_{2} \mathrm{O}_{5}$ & 29.11 & 27.14 & 28.18 & 27.94 & $\mathrm{P}$ & 0.957 & 0.923 & 0.946 & 0.964 \\
\hline $\mathrm{SiO}_{2}$ & 0.42 & 2.06 & 1.38 & 1.22 & $\mathrm{Si}$ & 0.016 & 0.083 & 0.055 & 0.050 \\
\hline $\mathrm{SO}_{3}$ & 0.94 & 0.09 & bdl & 0.09 & S & 0.027 & 0.003 & 0.000 & 0.003 \\
\hline $\mathrm{ThO}_{2}$ & 6.55 & 8.71 & 10.10 & 18.22 & Th & 0.058 & 0.080 & 0.091 & 0.169 \\
\hline $\mathrm{UO}_{2}$ & 0.22 & 0.36 & 0.25 & 0.42 & $\mathrm{U}$ & 0.002 & 0.003 & 0.002 & 0.004 \\
\hline $\mathrm{PbO}$ & 0.01 & 0.28 & 0.13 & 1.06 & $\mathrm{~Pb}$ & 0.000 & 0.003 & 0.001 & 0.012 \\
\hline \multirow[t]{5}{*}{ Total } & 100.18 & 98.70 & 99.56 & 97.61 & Total & 2.001 & 1.998 & 2.001 & 1.993 \\
\hline & & & & & $\sum$ LREE & 0.811 & 0.710 & 0.729 & 0.375 \\
\hline & & & & & $\sum$ MREE & 0.045 & 0.098 & 0.063 & 0.274 \\
\hline & & & & & $\sum A$ & 1.001 & 0.990 & 1.000 & 0.976 \\
\hline & & & & & $\bar{\Sigma} \mathrm{P}$ & 1.000 & 1.009 & 1.001 & 1.017 \\
\hline
\end{tabular}

* Atom per formula unit (apfu) are based on $4 \mathrm{O}$ atoms; bdl = below detection limit; $\sum$ LREE (light rare earth elements) $=\mathrm{La}+\mathrm{Ce}+\mathrm{Pr}+\mathrm{Nd} ; \sum$ MREE (middle rare earth elements) $=\mathrm{Sm}+\mathrm{Eu}+\mathrm{Gd}+\mathrm{Tb}+\mathrm{Dy} ; \sum A=\mathrm{LREE}+\mathrm{MREE}+\mathrm{Y}+$ $\mathrm{Ca}+\mathrm{Fe}+\mathrm{U}+\mathrm{Th}+\mathrm{Pb} ; \sum \mathrm{P}=\mathrm{P}+\mathrm{Si}+\mathrm{S}$ apfu. These analyses are close to the ideal formula, $A \mathrm{PO}_{4}$. 


\subsection{Single-Crystal X-ray Diffraction (SCXRD)}

Each monazite crystal was mounted on the tip of a glass fiber (diameter less than $0.1 \mathrm{~mm}$ ) using an adhesive. The mounted crystal was placed on a goniometer head and centered in the X-ray beam. SCXRD data were collected with a Nonius Kappa CCD diffractometer using a Bruker Nonius FR591(Madison, WI, USA) Rotating Anode with graphite mono-chromated MoK $\alpha$ radiation $(\lambda=0.71073 \AA)$. The generator setting was $50 \mathrm{kV}$ and $36 \mathrm{~mA}$, and the cryostat setting was set to 295 $\mathrm{K}$ (room temperature). The detector-crystal distance was fixed at $35 \mathrm{~mm}$. A total of 10 frames were collected for unit-cell determination with scan settings of $1^{\circ}$ rotation per frame (total rotation $=10^{\circ}$ ) and $22 \mathrm{~s}$ exposure time per frame. After obtaining satisfactory unit-cell parameters and mosaicity values, complete datasets were collected using $2^{\circ}$ per frame rotation with exposure of 42 to $122 \mathrm{~s}$ per frame. The diffraction spots were measured in full, scaled with Scalepak, corrected for Lorentz-polarization, and integrated using the Nonius program suite DENZO-SMN (version 2000) [19]. The data were corrected for absorption using the analytical absorption correction method. The centrosymmetric space group $P 21 / n$ was obtained based on systematic absence of reflections and structure factor statistics. The experimental techniques used in this study are well established, e.g., in References [20-26].

\subsection{Structure Refinements of SCXRD Data}

Full-matrix least-squares refinements were carried out with the SHELXL-97 program using neutral atom scattering factors [27]. The WinGX program suite (version 2020.1) was used as the platform for the structure refinements [28]. Atom coordinates for monazite-Ce and $\mathrm{SmPO}_{4}$ were used as the starting structural models [8]. The crystal structure of monazite was confirmed by direct methods followed by Fourier and difference Fourier maps. Anisotropic displacement parameters for all atoms were refined as well as the site occupancy factors (sofs) for the $A$ and P sites, in terms of the dominant atom in these sites. Details of data collection, processing, and refinements are given in Table 3 . The refined atom coordinates and displacement parameters are given in Table 4. Selected bond distances and angles are given in Table 5, which also includes bond-valence sum (BVS) values [29,30].

Table 3. Single-crystal structure refinement (single-crystal X-ray diffraction, SCXRD) data for the four monazite ${ }^{\S}$ samples used in this study.

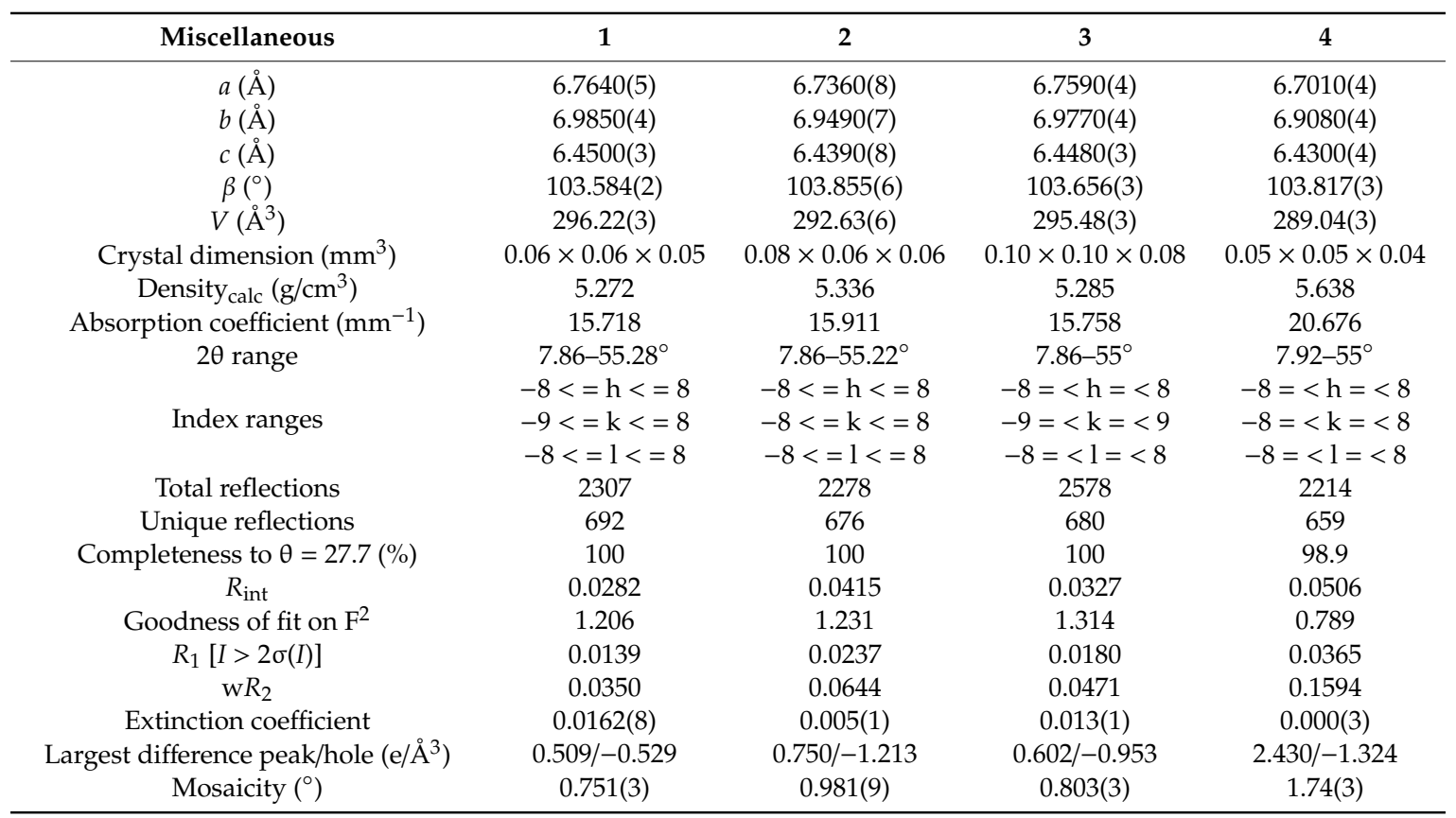

$\S$ Monoclinic; space group $=P 2_{1} / n$; formula unit, $Z=4$ based on $A \mathrm{PO}_{4}$. 
Table 4. Site occupancy factors (sofs), atom coordinates, and anisotropic displacement parameters $\left(U_{\mathrm{eq}}\right.$, $U_{\mathrm{ij}} ; \AA^{2}$ ) for the four monazite samples.

\begin{tabular}{|c|c|c|c|c|c|c|c|c|c|c|c|}
\hline \multicolumn{2}{|c|}{ Atom } & $x$ & $y$ & $z$ & $U_{\text {eq }}$ & $U_{11}$ & $U_{22}$ & $U_{33}$ & $U_{23}$ & $U_{12}$ & $U_{13}$ \\
\hline $\mathrm{Ce}^{*}$ & $1 \S$ & $0.28155(3)$ & $0.15901(3)$ & $0.10011(3)$ & $0.0111(1)$ & $0.0115(2)$ & $0.0113(2)$ & $0.0099(1)$ & $0.00123(6)$ & $0.00018(7)$ & $0.00156(8)$ \\
\hline $\mathrm{Ce}$ & 2 & $0.28047(5)$ & $0.15821(4)$ & $0.09972(5)$ & $0.0183(2)$ & $0.0193(2)$ & $0.0167(3)$ & $0.0169(2)$ & $0.0020(1)$ & $0.0000(1)$ & $0.0003(1)$ \\
\hline $\mathrm{Ce}$ & 3 & $0.28129(3)$ & $0.15862(3)$ & $0.09982(3)$ & $0.0107(1)$ & $0.0103(2)$ & $0.0093(2)$ & $0.0116(2)$ & $0.00156(7)$ & $0.00004(7)$ & $0.0006(1)$ \\
\hline Sm & 4 & $0.28004(8)$ & 0.15793(8) & $0.10002(7)$ & $0.0124(5)$ & $0.0119(6)$ & $0.0114(6)$ & $0.0133(6)$ & $0.0027(2)$ & $0.0001(3)$ & $0.0020(3)$ \\
\hline \multirow{4}{*}{$\mathrm{P}$} & 1 & $0.3039(1)$ & $0.1629(1)$ & $0.6122(1)$ & $0.0105(3)$ & $0.0108(5)$ & $0.0115(5)$ & $0.0090(4)$ & $0.0002(3)$ & $0.0008(3)$ & $0.0022(3)$ \\
\hline & 2 & $0.3028(2)$ & $0.1620(2)$ & $0.6115(2)$ & $0.0178(5)$ & $0.0209(8)$ & $0.0171(9)$ & $0.0141(8)$ & $-0.0002(5)$ & $0.0004(5)$ & $0.0018(5)$ \\
\hline & 3 & $0.3036(2)$ & $0.1625(1)$ & $0.6121(2)$ & $0.0107(4)$ & $0.0106(6)$ & $0.0104(6)$ & $0.0106(5)$ & $0.0001(2)$ & $0.0011(3)$ & $0.0017(4)$ \\
\hline & 4 & $0.3020(4)$ & $0.1625(3)$ & $0.6122(4)$ & $0.010(1)$ & $0.009(1)$ & $0.013(2)$ & $0.008(2)$ & $0.0007(5)$ & $0.0009(6)$ & $0.000(1)$ \\
\hline \multirow{4}{*}{ O1 } & 1 & $0.2488(4)$ & $0.0064(4)$ & $0.4425(4)$ & $0.0155(6)$ & $0.019(1)$ & $0.016(1)$ & $0.012(1)$ & $-0.0021(9)$ & $-0.000(1)$ & $0.0038(9)$ \\
\hline & 2 & $0.2474(6)$ & $0.0070(6)$ & $0.4389(7)$ & $0.022(1)$ & $0.026(2)$ & $0.019(2)$ & $0.021(2)$ & $-0.004(2)$ & $-0.002(2)$ & $0.005(2)$ \\
\hline & 3 & $0.2487(5)$ & $0.0059(4)$ & $0.4413(5)$ & $0.0167(7)$ & $0.019(2)$ & & & $-0.002(1)$ & $0.000(1)$ & $0.003(1)$ \\
\hline & 4 & $0.249(1)$ & $0.002(1)$ & $0.439(2)$ & $0.017(2)$ & $0.014(3)$ & $0.022(4)$ & $0.013(3)$ & $0.004(3)$ & $0.004(3)$ & $0.000(3)$ \\
\hline \multirow{4}{*}{$\mathrm{O} 2$} & 1 & $0.3816(4)$ & $0.3318(3)$ & $0.4993(4)$ & $0.0161(6)$ & $0.015(1)$ & $0.015(1)$ & $0.020(1)$ & $0.0030(9)$ & $-0.0016(9)$ & $0.007(1)$ \\
\hline & 2 & $0.3817(7)$ & $0.3327(6)$ & $0.4990(7)$ & $0.024(1)$ & $0.025(2)$ & $0.021(2)$ & $0.027(2)$ & $0.004(2)$ & $-0.002(2)$ & $0.007(2)$ \\
\hline & 3 & $0.3816(5)$ & $0.3323(4)$ & $0.4997(5)$ & $0.0173(7)$ & $0.015(2)$ & $0.016(2)$ & $0.022(2)$ & $0.004(1)$ & $-0.001(1)$ & $0.005(1)$ \\
\hline & 4 & $0.381(1)$ & $0.3317(1)$ & $0.501(1)$ & $0.018(2)$ & $0.020(4)$ & $0.009(4)$ & $0.029(4)$ & $-0.001(2)$ & $-0.008(2)$ & $0.012(4)$ \\
\hline \multirow{4}{*}{ O3 } & 1 & $0.4743(4)$ & $0.1061(4)$ & $0.8044(4)$ & $0.0170(6)$ & $0.015(1)$ & & & $-0.000(1)$ & & $-0.002(1)$ \\
\hline & 2 & $0.4744(7)$ & $0.1053(7)$ & $0.8064(7)$ & $0.029(1)$ & $0.028(2)$ & $0.031(2)$ & $0.022(2)$ & $-0.002(2)$ & $0.007(2)$ & $-0.004(2)$ \\
\hline & 3 & $0.4739(5)$ & $0.1050(5)$ & $0.8049(5)$ & $0.0185(7)$ & $0.016(2)$ & $0.020(2)$ & $0.017(1)$ & $-0.000(1)$ & $0.005(1)$ & $-0.003(1)$ \\
\hline & 4 & $0.475(2)$ & $0.106(1)$ & $0.807(2)$ & $0.019(2)$ & $0.009(3)$ & $0.019(4)$ & $0.023(3)$ & $0.002(3)$ & $0.001(3)$ & $-0.008(3)$ \\
\hline \multirow{4}{*}{ O4 } & 1 & $0.1268(4)$ & $0.2134(4)$ & $0.7104(4)$ & $0.0153(6)$ & $0.015(1)$ & $0.019(1)$ & $0.013(1)$ & $0.001(1)$ & $0.002(1)$ & $0.0049(9)$ \\
\hline & 2 & $0.1262(6)$ & $0.2117(7)$ & $0.7100(7)$ & $0.024(1)$ & $0.022(2)$ & $0.032(2)$ & $0.018(2)$ & $0.002(2)$ & $-0.003(2)$ & $0.003(2)$ \\
\hline & 3 & $0.1267(4)$ & $0.2133(5)$ & $0.7112(5)$ & $0.0157(7)$ & $0.012(1)$ & $0.020(2)$ & $0.015(1)$ & $0.002(1)$ & $0.001(1)$ & $0.002(1)$ \\
\hline & 4 & $0.124(1)$ & $0.217(1)$ & $0.710(1)$ & $0.017(2)$ & $0.028(4)$ & $0.013(4)$ & $0.013(3)$ & $0.002(2)$ & $0.004(3)$ & $0.013(3)$ \\
\hline
\end{tabular}

$\S 1,2,3$, and 4 are sample numbers; sof $=1$ for $\mathrm{P}$ and $\mathrm{O}$ atoms. ${ }^{*}$ In the A site, Ce sof was refined for samples 1 $[0.975(4)], 2[0.999(7)]$, and 3 [0.963(5)], whereas Sm was used for sample 4 [0.96(1)].

Table 5. Bond distances $(\AA)$, angles $\left(^{\circ}\right)$, and -bond valences for the four monazite samples used in this study.

\begin{tabular}{|c|c|c|c|c|c|c|c|c|c|c|}
\hline Bond/Angl & 1 & & 2 & & 3 & & [8] & & 4 & \\
\hline & & BV $\S$ & & BV & & BV & & BV & & BV \\
\hline$A-\mathrm{O} 1^{\prime}$ & $2.445(3)$ & 0.452 & $2.439(4)$ & 0.459 & $2.440(3)$ & 0.458 & $2.528(2)$ & 0.361 & $2.395(8)$ & 0.436 \\
\hline$-\mathrm{O} 1^{\prime \prime}$ & $2.509(3)$ & 0.380 & $2.481(4)$ & 0.410 & $2.503(3)$ & 0.386 & $2.461(2)$ & 0.433 & $2.484(7)$ & 0.343 \\
\hline$-\mathrm{O} 2^{\prime}$ & $2.554(2)$ & 0.336 & $2.526(4)$ & 0.363 & $2.544(3)$ & 0.346 & $2.776(3)$ & 0.185 & $2.515(7)$ & 0.315 \\
\hline$-\mathrm{O} 2^{\prime \prime}$ & $2.630(3)$ & 0.274 & $2.609(5)$ & 0.290 & $2.626(3)$ & 0.277 & $2.644(2)$ & 0.264 & $2.600(8)$ & 0.251 \\
\hline$-\mathrm{O} 2^{\prime \prime \prime}$ & $2.779(3)$ & 0.183 & $2.776(5)$ & 0.185 & $2.784(3)$ & 0.181 & $2.573(2)$ & 0.320 & $2.775(7)$ & 0.156 \\
\hline$-3^{\prime}$ & $2.461(3)$ & 0.433 & $2.443(5)$ & 0.454 & $2.454(3)$ & 0.441 & $2.585(3)$ & 0.309 & $2.430(7)$ & 0.397 \\
\hline$-\mathrm{O} 3^{\prime \prime}$ & $2.577(3)$ & 0.316 & $2.567(5)$ & 0.325 & $2.573(3)$ & 0.320 & $2.481(2)$ & 0.410 & $2.565(7)$ & 0.275 \\
\hline$-\mathrm{O} 4^{\prime}$ & $2.444(3)$ & 0.453 & $2.440(4)$ & 0.458 & $2.444(3)$ & 0.453 & $2.526(2)$ & 0.363 & $2.403(7)$ & 0.427 \\
\hline$-\mathrm{O} 4^{\prime \prime}$ & $2.514(2)$ & 0.375 & $2.503(4)$ & 0.386 & $2.506(3)$ & 0.383 & $2.455(2)$ & 0.440 & $2.507(6)$ & 0.322 \\
\hline $\begin{array}{l}<A-\mathrm{O}> \\
{[9]}\end{array}$ & $2.546(3)$ & $3.202^{+}$ & $2.532(4)$ & $3.330^{+}$ & $2.542(3)$ & $3.244^{\dagger}$ & $2.559(2)$ & $3.084^{\dagger}$ & $2.519(7)$ & $2.923^{\dagger}$ \\
\hline P-O1 & $1.530(3)$ & 1.221 & $1.528(4)$ & 1.228 & $1.534(3)$ & 1.208 & $1.534(3)$ & 1.208 & $1.550(8)$ & 1.157 \\
\hline$-\mathrm{O} 2$ & $1.542(3)$ & 1.182 & $1.548(4)$ & 1.163 & $1.545(3)$ & 1.173 & $1.545(3)$ & 1.173 & $1.529(7)$ & 1.225 \\
\hline$-\mathrm{O} 3$ & $1.533(3)$ & 1.212 & $1.540(4)$ & 1.189 & $1.535(3)$ & 1.205 & $1.534(3)$ & 1.208 & $1.539(6)$ & 1.192 \\
\hline$-\mathrm{O} 4$ & $1.522(3)$ & 1.248 & $1.517(5)$ & 1.265 & $1.524(3)$ & 1.241 & $1.531(3)$ & 1.218 & $1.526(7)$ & 1.235 \\
\hline $\begin{array}{l}<\mathrm{P}-\mathrm{O}> \\
{[4]}\end{array}$ & $1.532(3)$ & $4.863^{\dagger}$ & $1.533(4)$ & $4.845^{\dagger}$ & $1.535(3)$ & $4.828^{+}$ & $1.536(3)$ & $4.808^{\dagger}$ & $1.536(7)$ & $4.809^{\dagger}$ \\
\hline O1-P-O2 & 105.1(2) & & $104.6(3)$ & & $105.1(2)$ & & 113.7 & & $104.8(4)$ & \\
\hline O1-P-O3 & $113.8(2)$ & & $114.6(3)$ & & $113.8(2)$ & & 103.9 & & $113.7(7)$ & \\
\hline O1-P-O4 & $112.4(2)$ & & $112.7(3)$ & & $112.7(2)$ & & 113.7 & & $113.8(4)$ & \\
\hline O2-P-O3 & $107.8(2)$ & & $107.6(3)$ & & $107.9(2)$ & & 112.4 & & 107.3(5) & \\
\hline O2-P-O4 & $114.1(2)$ & & $114.4(3)$ & & $114.0(2)$ & & 105.2 & & $113.5(4)$ & \\
\hline O3-P-O4 & $103.8(1)$ & & 103.2(3) & & $103.5(2)$ & & 108.1 & & $103.9(4)$ & \\
\hline $\begin{array}{l}<\mathrm{O}-\mathrm{P}-\mathrm{O}> \\
{[6]}\end{array}$ & $109.5(2)$ & & 109.5(3) & & $109.5(2)$ & & 109.5 & & $109.5(5)$ & \\
\hline
\end{tabular}

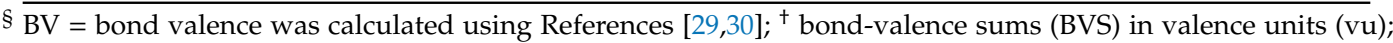
literature data is included [8]. 


\section{Results}

\subsection{Chemical Composition of Monazite-Ce and Sm-Rich Monazite}

The EPMA chemical compositions for the four monazite samples are (see Table 2):

1: $\quad\left(\mathrm{Ce}_{0.40} \mathrm{La}_{0.20} \mathrm{Nd}_{0.17} \mathrm{Ca}_{0.08} \mathrm{Th}_{0.06} \mathrm{Pr}_{0.04} \mathrm{Sm}_{0.02} \mathrm{Gd}_{0.01} \mathrm{Y}_{0.01}\right)_{\Sigma 0.99}\left(\mathrm{P}_{0.96} \mathrm{~S}_{0.03} \mathrm{Si}_{0.02}\right)_{\Sigma 1.01} \mathrm{O}_{4}$,

2: $\quad\left(\mathrm{Ce}_{0.33} \mathrm{Nd}_{0.22} \mathrm{La}_{0.11} \mathrm{Y}_{0.08} \mathrm{Th}_{0.08} \mathrm{Sm}_{0.06} \operatorname{Pr}_{0.05} \mathrm{Gd}_{0.03} \mathrm{Dy}_{0.01} \mathrm{Ca}_{0.01}\right)_{\Sigma 0.98}\left(\mathrm{P}_{0.92} \mathrm{Si}_{0.08}\right)_{\Sigma 1.00} \mathrm{O}_{4}$,

3: $\quad\left(\mathrm{Ce}_{0.37} \mathrm{La}_{0.17} \mathrm{Nd}_{0.16} \mathrm{Th}_{0.09} \mathrm{Y}_{0.07} \mathrm{Pr}_{0.04} \mathrm{Ca}_{0.04} \mathrm{Sm}_{0.03} \mathrm{Gd}_{0.02} \mathrm{Dy}_{0.01}\right)_{\Sigma 1.00}\left(\mathrm{P}_{0.95} \mathrm{Si}_{0.06}\right)_{\Sigma 1.01} \mathrm{O}_{4}$, and

4: $\quad\left(\mathrm{Sm}_{0.19} \mathrm{Ce}_{0.19} \mathrm{Th}_{0.17} \mathrm{Ca}_{0.13} \mathrm{Nd}_{0.10} \mathrm{Gd}_{0.08} \mathrm{La}_{0.06} \mathrm{Pr}_{0.03} \mathrm{Y}_{0.02} \mathrm{~Pb}_{0.01}\right)_{\Sigma 0.98}\left(\mathrm{P}_{0.96} \mathrm{Si}_{0.05}\right)_{\Sigma 1.01} \mathrm{O}_{4}$.

The Ce atom is dominant in samples 1, 2, and 3, whereas sample 4 is Sm-rich and contains the most Th and Ca atoms. In fact, sample 4 contains 0.327 apfu non-lanthanide cations, followed by sample 3 (0.208), sample 2 (0.182), and sample 1 (0.145 apfu). The $A$ and P sites are fully occupied. Sample 4 contains equal amount of Ce and Sm atoms ( 0.19 apfu) and this amount of Ce atoms is about half of that in samples 1 and 3. Th atom is present in all the samples, but sample 4 contains the highest amount (0.17 apfu). The monazite structure preferentially accommodates $\mathrm{La}^{3+}, \mathrm{Ce}^{3+}, \mathrm{Pr}^{3+}, \mathrm{Nd}^{3+}, \mathrm{Sm}^{3+}$, $\mathrm{Eu}^{3+}, \mathrm{Gd}^{3+}, \mathrm{Tb}^{3+}$, and $\mathrm{Dy}^{3+}$ cations. However, $\mathrm{Ho}^{3+}, \mathrm{Er}^{3+}, \mathrm{Tm}^{3+}, \mathrm{Yb}^{3+}$, and $\mathrm{Lu}^{3+}$ cations are generally not found in monazite [12]. The $\mathrm{La}^{3+}$ cation has the largest ionic radius $(1.216 \AA)$ and lowest atomic number (57), whereas the $\mathrm{Lu}^{3+}$ cation has the smallest ionic radius (1.032 $\AA$ ) and highest atomic number (71) [31], so cations within this range substitute for each other. A charge-balancing reaction may be written as $\left(\mathrm{Ca}^{2+}+\mathrm{Th}^{4+}\right)+\left(\mathrm{Si}^{4+}+\mathrm{S}^{6+}\right)=2 \mathrm{P}^{5+}+2(\mathrm{Ln}, \mathrm{Y})^{3+}$. Numerous substitutions imply a wide range of chemical flexibility for monazite.

\subsection{Variations of Unit-Cell Parameters}

The $a, b, c$, and $\beta$ unit-cell parameters vary linearly with unit-cell volume, $V$, for the synthetic compounds $\mathrm{SmPO}_{4}, \mathrm{PrPO}_{4}, \mathrm{CePO}_{4}$, and $\mathrm{LaPO}_{4}$ (Figure 2) [8]. The $a$ and $b$ unit-cell parameters for our samples are close to the linear line drawn using the literature data in Reference [8] (Figure 2a,b). The $a, \mathrm{~b}$, and $c$ unit-cell parameters for our samples vary linearly with $V$, but not the $\beta$ angle (Figure 2d). Such linear relations were also observed in other minerals [32-36]. The red trend lines for our unit-cell parameters are different from those for the synthetic samples (Figure 2). The largest $a$ and $b$ unit-cell parameters obtained for sample 1 differ by about 0.0263 and $0.0353 \AA$ respectively, from the pure $\mathrm{CePO}_{4}$ compound (Figure $\left.2 \mathrm{a}, \mathrm{b}\right)$, because the weighted average ionic radii for sample $1(=1.182 \AA$ ) differs slightly from $\mathrm{CePO}_{4}(=1.196 \AA)$. The weighted average radii values were calculated based on the $A$ site cations and their ionic radii [31].

The $c$ unit-cell parameter for samples 1,2, and 3 are within $0.011 \AA$, whereas the variations of the $c$ unit-cell parameters for $\mathrm{SmPO}_{4}, \mathrm{PrPO}_{4}, \mathrm{CePO}_{4}$, and $\mathrm{LaPO}_{4}$ are large (Figure 2c). However, the $c$ unit-cell parameter for sample 4 is less than our other samples. The chemical composition for sample 4 is quite different from the other samples, as pointed out above. Two monazite samples have the largest $c$ values [11] (Figure 2c). The polyhedral arrangement along [001] in monazite contains O-O edge sharing between $A \mathrm{O}_{9}$ polyhedra and $\mathrm{PO}_{4}$ tetrahedra (Figure $1 \mathrm{a}$ ), and the $\mathrm{PO}_{4}$ tetrahedra are stacked along this direction, resulting in a restricted variation of the $c$ parameter. Two $\mathrm{O}$ atoms are shared by two adjacent $A$ atoms forming a zigzag chain along the [100] direction (Figure 1b). Two $\mathrm{O}$ atoms are also partly shared by adjacent $\mathrm{P}$ atoms along the [010] direction. The $A$ polyhedra along the [100] direction are stacked with each other. Variations of the $a$ unit-cell parameter depend on the cations occupying the $A$ site. Along the [010] direction, the $A \mathrm{O}_{9}$ polyhedra and $\mathrm{PO}_{4}$ tetrahedra are linked by a corner and have enough space to distort and give rise to variations in the [010] direction (Figure 1b).

The $\beta$ unit-cell parameter decreases with increasing $V$, and our samples plot close to the linear line (Figure 2d). If the $a, b$, and $c$ unit-cell parameters increase, then $A$ and $\mathrm{P}$ cations come closer to each other and repulsion occurs, which may be the reason for the decrease in the $\beta$ angle. 

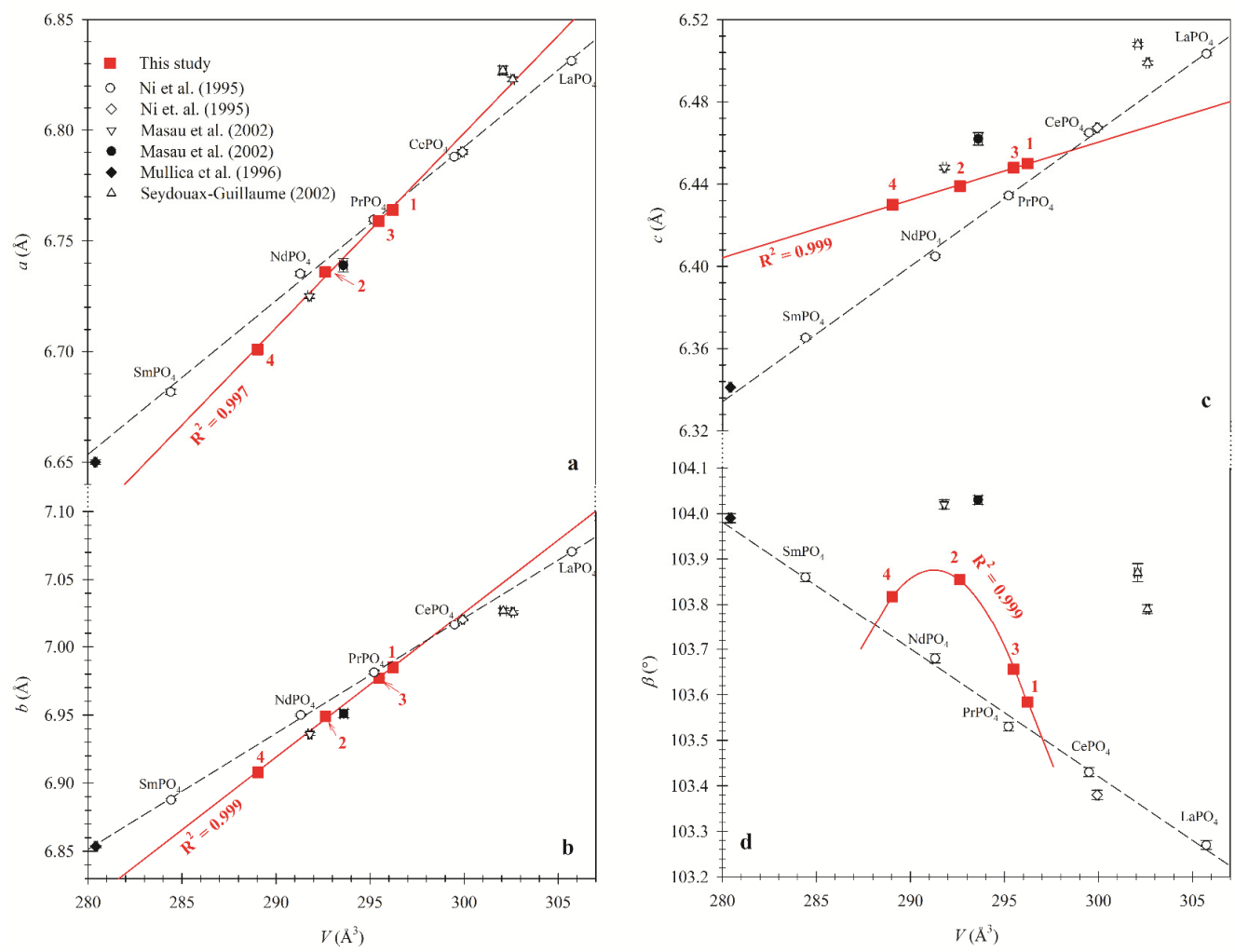

Figure 2. Variations of unit-cell parameters in monazite. The dashed linear lines are fitted to the data for the synthetic compounds $\mathrm{LaPO}_{4}, \mathrm{CePO}_{4}, \mathrm{NdPO}_{4}$, and $\mathrm{SmPO}_{4}$ [8]. The $a, \mathrm{~b}$, and $c$ unit-cell parameters from this study vary linearly (red lines) with $V$ in $(\mathbf{a}-\mathbf{c})$ respectively, whereas the $\beta$ angle in (d) does not vary in a linear manner. The literature data are included $[8,10,11,37]$.

\subsection{Site Occupancy Factor (sof) and Chemical Composition}

The chemical compositions for our samples were discussed above. The sof for $A$ site for our samples were refined using the dominant $\mathrm{Ce}$ or Sm atom and the values are 0.975(4), 0.999(7), 0.963(5), and $0.96(1)$ (Table 4). These values indicate that the $A$ site is $96 \%$ to $100 \%$ fully occupied by Ce or Sm atoms and may also contain a small amount of other heavier atoms to give an occupancy slightly $<1$. The $A$ site for samples 1, 2, and 3 contains $0.404,0.330$, and 0.367 apfu Ce, whereas sample 4 contains 0.193 apfu Sm (Table 2). The number of electrons for $\mathrm{Ln}^{3+}$ cations are very close to each other and the sofs obtained for the $A$ site using either Ce or Sm atom are biased, as indicated by their chemical compositions. EPMA chemical data are commonly used to fix the $A$ site occupancy. In this study, similar structural results were obtained either by fixing the $A$ site occupancy or refining it.

\subsection{Bond Distances and Chemical Compositions}

The average $\langle A$-O $>$ distances vary linearly with $V$, whereas the average $\langle\mathrm{P}-\mathrm{O}\rangle$ distance is nearly constant, as expected (Table 5, Figure 3). Data from the literature [8,9] are close to our linear lines. $\mathrm{PO}_{4}$ is a rigid tetrahedron with a constant P-O distance of $1.528 \AA$, which is similar to that reported for apatite. Sample 2 has an average $<A-\mathrm{O}>$ distance of 2.532(5) $\AA$ compared to $2.559 \AA$ [8], indicating the presence of cations that have smaller ionic radii at the A site. The weighted average ionic radii were calculated based on the $A$ site cations and their ionic radii [31]. This ionic radius increases linearly with the average $\left\langle A-\mathrm{O}>\right.$ distance (Figure 4). The main substituted cations at the $\mathrm{A}$ site are $\mathrm{Y}^{3+}, \mathrm{Ca}^{2+}$, $\mathrm{Th}^{4+}$, and $\mathrm{U}^{4+}$, and they have ionic radii smaller than $\mathrm{Ln}^{3+}$ cations. The average $<A-\mathrm{O}>$ distances vary with substitutions between $\mathrm{Ln}^{3+}$ and other cations. 


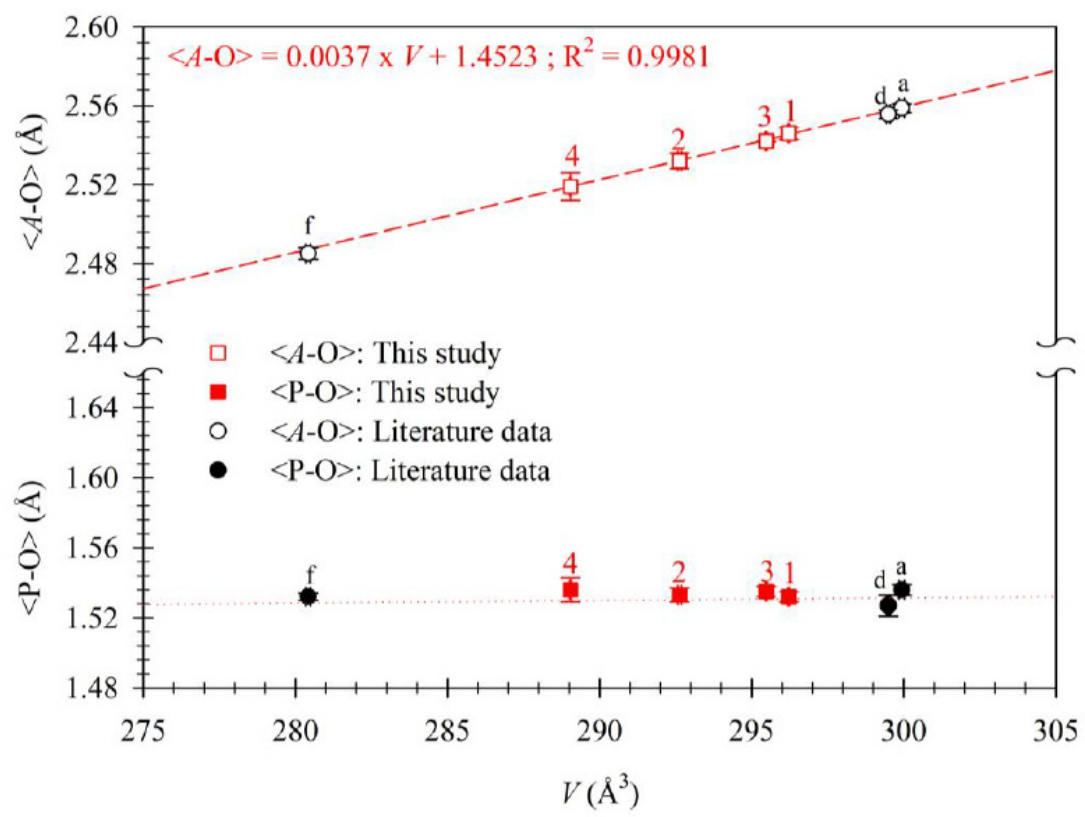

Figure 3. Average $\langle A-\mathrm{O}>$ and $<\mathrm{P}-\mathrm{O}>$ distances in monazite. The dashed linear line is fitted to data from this study. The literature data are a: monazite-Ce and d: $\mathrm{CePO}_{4}$ [8], and $\mathrm{f}:\left[\mathrm{Sm}_{0.5} \mathrm{~Tb}_{0.5}\right] \mathrm{PO}_{4}$ [37]. The average $<A-\mathrm{O}>$ distances vary linearly with $V$. Average $<\mathrm{P}-\mathrm{O}>=1.528 \AA$ (dotted line).

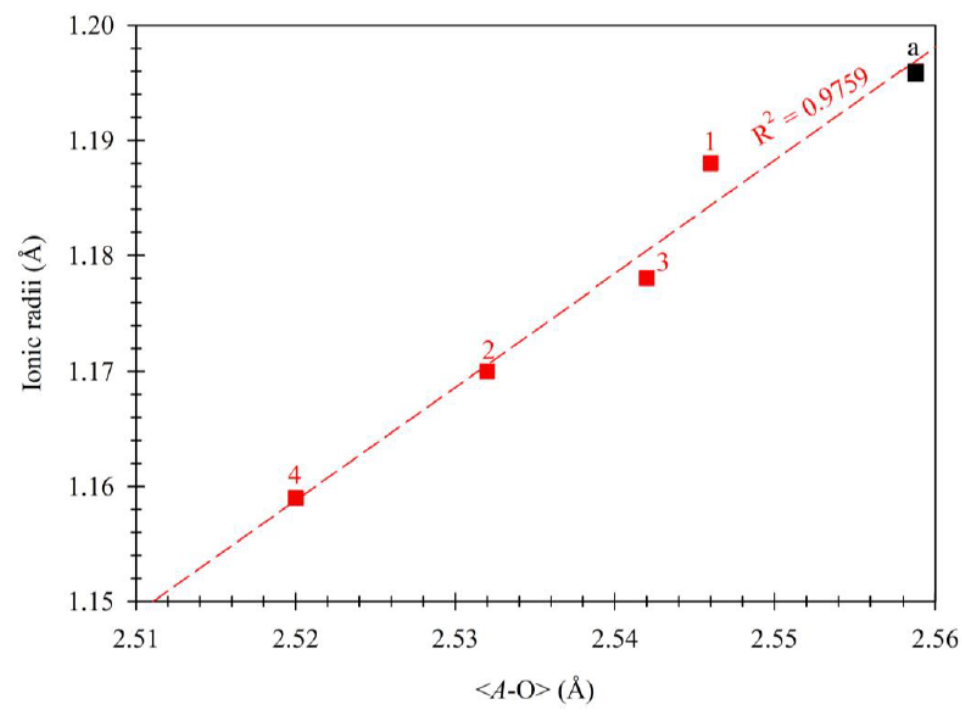

Figure 4. Average $\langle A-\mathrm{O}\rangle$ distances vary linearly with the weighted average ionic radii of the $A$ site cations. The red dashed linear line is fitted to data from this study, whereas "a" is from Reference [8]. The ionic radii for $A$ site cations control the average $<A-\mathrm{O}>$ distances in monazite.

The $A$-P cation-cation distance is shorter than the $A$ - $\mathrm{P}^{\prime}$ distance (Figure 5$)$. The $A$ - $A$ distances vary from 4.0228(9) (sample 4) to 4.0628 (3) $\AA$ (sample 1). The cation-cation distances vary linearly with the weighted average ionic radii of $A$ site cations (Figure 5). The two $A$-P distances for synthetic light rare earth phosphates vary linearly with the ionic radii of light $\mathrm{Ln}^{3+}$ cations, but the degree of variations differ [8]. This study shows that the degree of variations of the two $A$-P distances are not significant, whereas the $A-A$ distances show significant variations (Figure 5). 


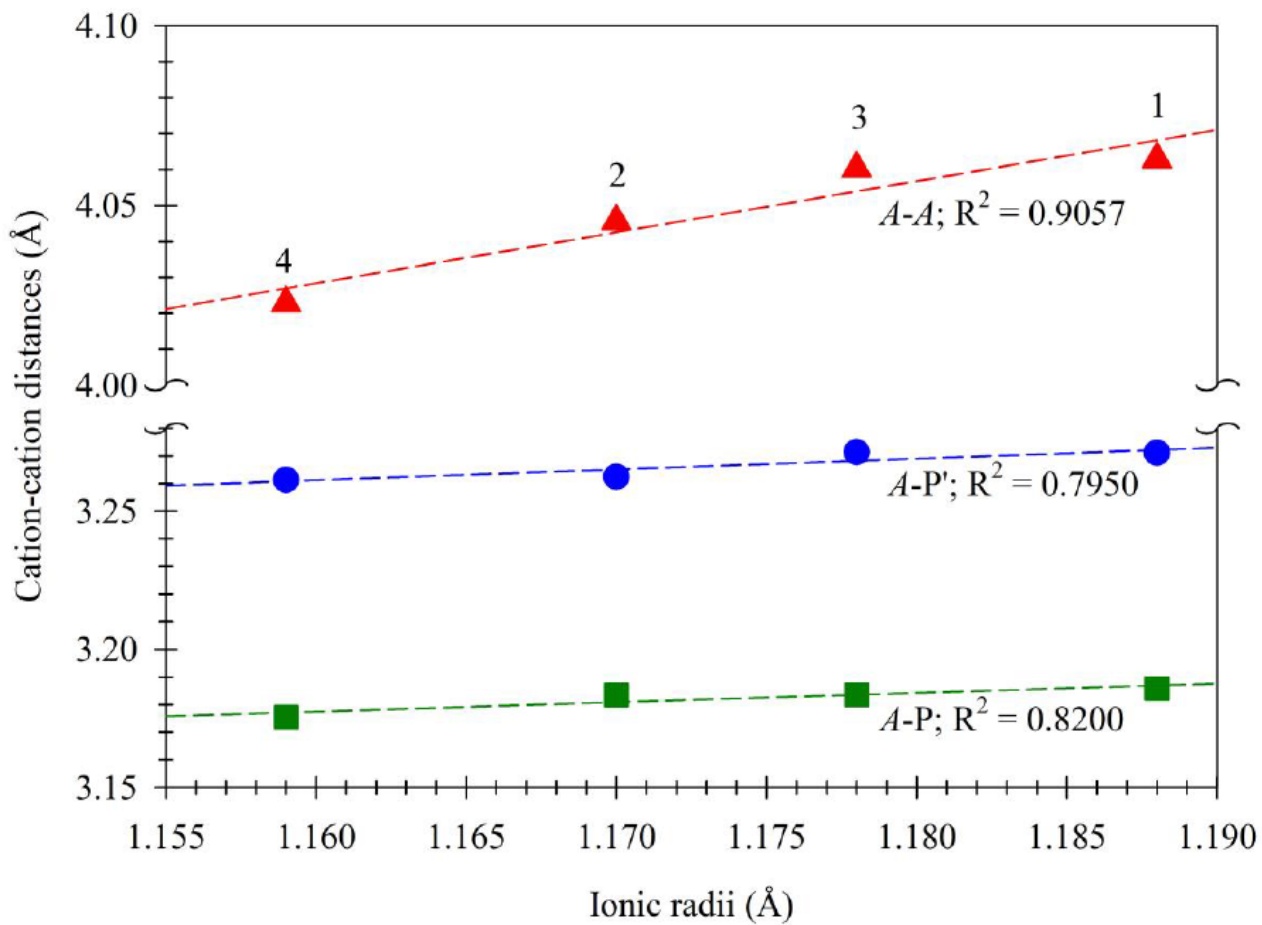

Figure 5. Variations of cation-cation distances with weighted average ionic radii for the $A$ site cations. Linear dashed lines are fits to data from this study.

The coordination number for the $A^{3+}$ cation to the $\mathrm{O}$ atoms is $9[2,8,15]$. However, this coordination number may be 8 [38]. The $A^{3+}-\mathrm{O}$ bonds are not directional and the coordination may vary from 3 to 12 [39]. However, the most common coordination number for $\mathrm{Ln}^{3+}$ is 8 or 9 [39].

The bond valences (BV) for each of the $9 \mathrm{~A}-\mathrm{O}$ and $4 \mathrm{P}-\mathrm{O}$ distances and their bond valance sum (BVS) in valence units (vu) were calculated $[29,30]$ (Table 5). The BVS for the $A$ site are 3.202, 3.330, 3.244 , and $2.923 \mathrm{vu}$ for samples 1 to 4 , and 3.084 for monazite-Ce [8]. The ideal BVS for the $A$ site is $3 \mathrm{vu}$. If $A$ is coordinated to 8 instead of $9 \mathrm{O}$ atoms, the BVS are 3.01, 3.145, and $3.063 \mathrm{vu}$ for samples 1 , 2 , and 3 , and these values are close to the ideal $3 \mathrm{vu}$ (Table 5). Therefore, the longest $A$-O2"' distance may be excluded, so the $A$ polyhedron is 8-coordinated in Ce-rich monazite, but 9 for sample 4 .

\section{Conclusions}

Except for the $\beta$ angle, the $a, b$, and $c$ unit-cell parameters for monazite vary linearly with $V$ because of the type of cations occupying the $A$ site. The average $<A-\mathrm{O}>$ distances also vary linearly with $V$, whereas the average $\left\langle\mathrm{P}-\mathrm{O}>\right.$ distance is constant, so $\mathrm{PO}_{4}$ is a rigid tetrahedron. Bond-valence sums (BVS) around the $A$ site indicate that it is coordinated to $8 \mathrm{O}$ atoms in samples 1 to 3 , but 9-coordinated in sample 4 . The $A$ site can accommodate a wide range of cations that have similar ionic radii. This chemical flexibility at the $A$ site permits the accommodation of $\mathrm{Pu}$ atoms. During nuclear power generation, ${ }^{238} \mathrm{U}$ in the fuel system absorbs a neutron and produces ${ }^{239} \mathrm{Pu}$. The monazite structure is stable over a long geologic time, so it can be used for sequestration of $\mathrm{Pu}$ atoms over a million years.

Author Contributions: M.M.Z. carried out the experiments (EPMA, SCXRD). M.M.Z. and S.M.A. analyzed the data and contributed to writing and editing the manuscript. All authors have read and agreed to the published version of the manuscript.

Funding: This research was funded by a NSERC Discovery Grant to S.M.A., grant number 10013896.

Acknowledgments: We thank the four anonymous reviewers for useful comments that helped improve this paper. We thank Masood Parvez for help with the single-crystal X-ray diffraction data collection and Robert Marr for his help with EPMA data collection. 
Conflicts of Interest: The authors declare no conflict of interest.

\section{References}

1. Boatner, L.A.; Sales, B.C. Monazite. In Radioactive Waste Forms for the Future; Lutze, W., Ewing, R.C., Eds.; Elsevier: Amsterdam, The Netherlands, 1988; pp. 495-564.

2. Clavier, N.; Podor, R.; Dacheux, N. Crystal chemistry of the monazite structure. J. Eur. Ceram. Soc. 2011, 31, 941-976. [CrossRef]

3. Gramaccioli, C.M.; Segalstad, T.V. A uranium- and thorium-rich monazite from a south-alpine pegmatite at Piona, Italy. Am. Mineral. 1978, 63, 757-761.

4. Van-Emden, B.; Graham, J.; Lincoln, F.J. The incorporation of actinides in monazite and xenotime from placer deposits in Western Australia. Can. Mineral. 1997, 35, 95-104.

5. Mooney, R.C.L. Crystal structures of a series of rare earth phosphates. J. Chem. Phys. 1948, 16, 1003. [CrossRef]

6. Ueda, T. Re-examination of the crystal structure of monazite. J. Jpn. Assoc. Mineral. Petrol. Econ. Geol. 1967, 58, 170-179. [CrossRef]

7. Ghouse, K.M. Refinement of the crystal structure of heat-treated monazite crystal. Indian J. Pure Appl. Phys. 1968, 2, 265-268.

8. Ni, Y.; Hughes, J.M.; Mariano, A.N. Crystal chemistry of the monazite and xenotime structures. Am. Mineral. 1995, 80, 21-26. [CrossRef]

9. Mullica, D.F.; Grossie, D.A.; Boatner, L.A. Coordination geometry and structural determinations of $\mathrm{SmPO}_{4}$, $\mathrm{EuPO}_{4}$ and $\mathrm{GdPO}_{4}$. Inorg. Chim. Acta 1985, 109, 105-110. [CrossRef]

10. Masau, M.; Cerny, P.; Cooper, M.A.; Chapman, R.; Grice, J.D. Monazite-Sm, a new member of the monazite group from the Annie claim \#3 granite pegmatite, southeastern Manitoba. Can. Mineral. 2002, 40, 1649-1655.

11. Seydoux-Guillaume, A.M.; Wirth, R.; Nasdala, L.; Gottschalk, M.; Montel, J.M.; Heinrich, W. An XRD, TEM and Raman study of experimentally annealed natural monazite. Phys. Chem. Miner. 2002, 29, 240-253. [CrossRef]

12. Boatner, L.A. Synthesis, structure and properties of monazite, pretulite and xenotime. In Phosphates. Reviews in Mineralogy and Geochemistry; Kohn, M.L., Rakovan, J., Hughes, J.M., Eds.; Mineralogical Society of America: Chantilly, VA, USA, 2002; Volume 48, pp. 87-120.

13. Dacheux, N.; Clavier, N.; Podor, R. Monazite as a promising long-term radioactive waste matrix: Benefits of high-structural flexibility and chemical durability. Am. Mineral. 2013, 98, 833-847. [CrossRef]

14. Crichton, W.A.; Parise, J.B.; Antao, S.M.; Grzechnik, A. Evidence for monazite-, barite- and $\mathrm{AgMnO}_{4}$ (distorted barite)-type structures of $\mathrm{CaSO}_{4}$ at high pressure and temperature. Am. Mineral. 2005, 90, $22-27$. [CrossRef]

15. Beall, G.W.; Boatner, L.A.; Mullica, D.F.; Milligan, W.O. The structure of cerium ortho-phosphate, a synthetic analog of monazite. J. Inorg. Nucl. Chem. 1981, 43, 101-105. [CrossRef]

16. Zaman, M.; Schubert, M.; Antao, S. Elevated radionuclide concentrations in heavy mineral-rich beach sands in the Cox's Bazar region, Bangladesh and related possible radiological effects. Isot. Environ. Health Stud. 2012, 48, 512-525. [CrossRef] [PubMed]

17. Zaman, M.M.; Antao, S.M. Crystal chemistry and structural variations for zircon samples from various localities. Minerals 2020, 10, 947. [CrossRef]

18. Pyle, J.M.; Spear, F.S.; Wark, D.A. Electron microprobe analysis of REE in apatite, monazite, and xenotime: Protocols and pitfalls. In Phosphates. Reviews in Mineralogy and Geochemistry; Kohn, M.J., Rakovan, J., Hughes, J.M., Eds.; Mineralogical Society of America: Washington, DC, USA, 2002; Volume 48, pp. 337-362.

19. Otwinowski, Z.; Minor, W. Processing of X-ray diffraction data collected in oscillation mode. In Methods in Enzymology: Macromolecular crystallography A276; Carter, C.W., Jr., Sweet, R.M., Eds.; Academic Press: New York, NY, USA, 1997; pp. 307-326.

20. Antao, S.M.; Dhaliwal, I. Growth Oscillatory Zoning in Erythrite, Ideally $\mathrm{Co}_{3}\left(\mathrm{AsO}_{4}\right)_{2} \cdot 8 \mathrm{H}_{2} \mathrm{O}$ : Structural Variations in Vivianite-Group Minerals. Minerals 2017, 7, 136. [CrossRef]

21. Antao, S.M.; Hassan, I.; Crichton, W.A.; Parise, J.B. Effects of high pressure and temperature on cation ordering in magnesioferrite, $\mathrm{MgFe}_{2} \mathrm{O}_{4}$, using in situ synchrotron X-ray powder diffraction up to $1430 \mathrm{~K}$ and 6 GPa. Am. Mineral. 2005, 90, 1500-1505. [CrossRef] 
22. Antao, S.M.; Hassan, I.; Mulder, W.H.; Lee, P.L. The R-3c $\rightarrow$ R-3m transition in nitratine, $\mathrm{NaNO}_{3}$, and implications for calcite, $\mathrm{CaCO}_{3}$. Phys. Chem. Miner. 2008, 35, 545-557. [CrossRef]

23. Ehm, L.; Michel, F.M.; Antao, S.M.; Martin, C.D.; Lee, P.L.; Shastri, S.D.; Chupas, P.J.; Parise, J.B. Structural changes in nanocrystalline mackinawaite (FeS) at high pressure. J. Appl. Crystallogr. 2009, 42, 15-21. [CrossRef]

24. Hassan, I.; Antao, S.M.; Hersi, A.A. Single-crystal XRD, TEM, and thermal studies of the satellite reflections in nepheline. Can. Mineral. 2003, 41, 759-783. [CrossRef]

25. Hassan, I.; Antao, S.M.; Parise, J.B. Haüyne: Phase transition and high-temperature structures obtained from synchrotron radiation and Rietveld refinements. Mineral. Mag. 2004, 68, 499-513. [CrossRef]

26. Parise, J.B.; Antao, S.M.; Michel, F.M.; Martin, C.D.; Chupas, P.J.; Shastri, S.; Lee, P.L. Quantitative high-pressure pair distribution function analysis. J. Synchrotron Radiat. 2005, 12, 554-559. [CrossRef] [PubMed]

27. Sheldrick, G.M. A short history of SHELX. Acta Crystallogr. 1998, A64, 112-122.

28. Farrugia, L.J. Win GX and ORTEP for Windows: An update. J. Appl. Crystallogr. 2012, 45, 849-854. [CrossRef]

29. Brown, I.D. The Chemical Bond in Inorganic Chemistry: The Bond Valence Model; Oxford University Press: New York, NY, USA, 2002.

30. Brown, I.D.; Altermatt, D. Bond-valence parameters obtained from a systematic analysis of the inorganic crystal structure database. Acta Crystallogr. 1985, B41, 244-247. [CrossRef]

31. Shannon, R.D. Revised effective ionic radii and systematic studies of interatomic distances in halides and chalcogenides. Acta Crystallogr. 1976, A32, 751-767. [CrossRef]

32. Antao, S.M. Three cubic phases intergrown in a birefringent andradite-grossular garnet and their implications. Phys. Chem. Miner. 2013, 40, 705-716. [CrossRef]

33. Antao, S.M. The mystery of birefringent garnet: Is the symmetry lower than cubic? Powder Diffr. 2013, 28, 281-288. [CrossRef]

34. Antao, S.M. Crystal chemistry of birefringent hydrogrossular. Phys. Chem. Miner. 2015, 42, $455-474$. [CrossRef]

35. Antao, S.M.; Klincker, A.M. Origin of birefringence in andradite from Arizona, Madagascar, and Iran. Phys. Chem. Miner. 2013, 40, 575-586. [CrossRef]

36. Antao, S.M.; Mohib, S.; Zaman, M.; Marr, R.A. Ti-rich andradites: Chemistry, structure, multi-phases, optical anisotropy, and oscillatory zoning. Can. Mineral. 2015, 53, 133-158. [CrossRef]

37. Mullica, D.F.; Sappenfield, E.L.; Boatner, L.A. Monazite- and zircon-type structures of seven mixed (Ln/Ln) $\mathrm{PO}_{4}$ compounds. Inorg. Chinica Acta 1996, 244, 247-252. [CrossRef]

38. Muller, O.; Roy, R. Crystal Chemistry of Non-Metallic Materials: Volume 4; Springer: New York, NY, USA, 1975.

39. Huang, C. Rare Earth Coordination Chemistry_Fundamentals and Applications; John Wiley \& Sons Pte Ltd.: Singapore, 2010.

Publisher's Note: MDPI stays neutral with regard to jurisdictional claims in published maps and institutional affiliations.

(C) 2020 by the authors. Licensee MDPI, Basel, Switzerland. This article is an open access article distributed under the terms and conditions of the Creative Commons Attribution (CC BY) license (http://creativecommons.org/licenses/by/4.0/). 